\title{
Missing and misidentified museum specimens hinder long-term monitoring: a case study of shell-bearing gastropods from the Kola Meridian transect, Barents Sea
}

\author{
Ivan O. Nekhaev' 1 [ \& Alexey V. Merkuliev² \\ 'Department of Applied Ecology, Faculty of Biology, Saint Petersburg State University, Saint Petersburg, Russia; \\ ${ }^{2}$ Laboratory of Marine Research, Zoological Institute of Russian Academy of Sciences, Saint Petersburg, Russia
}

\begin{abstract}
The consequences of global change cannot be estimated without long-term

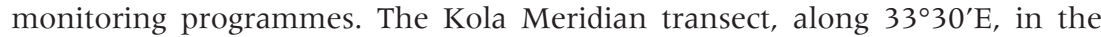
Barents Sea is the longest term monitoring area in the Arctic. Regular (usually annual) hydrobiological benthic surveys along that transect have been performed since 1899. Materials stored in museum collections remain the main source of the faunistic information obtained during the surveys, while only a minor part of these data was published. We reexamined all samples of shell-bearing gastropods from the Kola Meridian stored at the Zoological Institute of the Russian Academy of Sciences and at Saint Petersburg State University. We found only 159 museum lots from 73 samples, which constitute a very small portion of the total material collected along the transect. Approximately onethird of them (54 lots) was misidentified or includes individuals that cannot be identified at species level. The species composition revealed by museum materials differs substantially from published checklists. Majority of the studied samples (40) were collected during 1899-1920. However, the extant collections do not provide a reliable baseline for the Kola Meridian. We propose that the storage of zoological material in public collections should be considered as an essential part of long-term monitoring programmes.
\end{abstract}

To access the supplementary material, please visit the article landing page

\section{Introduction}

Arctic marine ecosystems have undergone significant changes during the last century primarily on account of climatic shifts, fisheries and pollution. However, our ability to detect changes is limited by the availability of historical environmental data. Long-term monitoring programmes are the main sources of such information. In the Arctic seas, the longest time series of observations have been performed at the Kola Meridian.

The Kola Meridian (also known as the Kola Transect, Kola Section and Kolskiy Meridian) is a standard hydrobiological and hydrological transect in the Barents Sea. The transect starts at $69^{\circ} 30^{\prime} \mathrm{N}$, near the mouth of the Kola Inlet, and runs north along the $33^{\circ} 30^{\prime}$ E meridian. Its northern part lies approximately midway between the archipelagos of Svalbard and Novaya Zemlya. It usually

\section{Keywords}

Arctic; climate change; historical collections; benthos; gastropods

\section{Correspondence}

Ivan O. Nekhaev, Department of Applied Ecology, Faculty of Biology, Saint Petersburg State University, Universitetskaya Emb. 7-9, RU-199034, Saint Petersburg, Russia.

E-mail: inekhaev@gmail.com

\section{Abbreviations}

DH: Department of Hydrobiology, Saint Petersburg State University

ZIN: Zoological Institute, Russian Academy of Sciences 
Meridian since its establishment at the conclusion of the 19th century because different institutions were involved in the fieldwork and many archives have been lost. The samples of benthic fauna were usually taken once or twice a year during the periods of 1899-1906, 1921-1939, 1947-1957, 1968-69 and from 1995 until the present day (Strelkova 2016). Occasionally, sampling was carried out in the intervals between these periods during some studies not aimed at monitoring; nevertheless, they contributed to the knowledge of species distribution along the transect.

Until the last decade of the 20th century, only three papers dedicated to the bottom fauna of the Kola Meridian were published. The most comprehensive study was performed by Derjugin (1924) and was based exclusively on results of 1921-1922. The materials collected in 1925 were described by Tanasijčuk (1927). Both aforementioned studies were descriptive and contained species lists of all the macrobenthic taxa detected at each station. Nessis (1960) analysed the data pertaining to the distribution of benthic macroorganisms obtained during the period 1933-1959. He suggested that a proportion of the Arctic and boreal species along the transect had changed in response to perennial fluctuations of the water temperature. Unfortunately, the raw data used by Nessis (1960) are not presented in his publication, and the statistical basis is insufficient for his conclusions.

The majority of recent benthic surveys along the transect deal with a relatively short (decade or less) series of observations (Frolova et al. 2007; Dikaeva 2009; Zimina \& Ljubina 2016). No attempts have been made to generalize the data sets obtained during longer periods. On the contrary, environmental studies and investigation of pelagic communities are often operating with data obtained since the beginning of the regular monitoring along the Kola Meridian (Tande et al. 2000; Titov 2001; Boitsov et al. 2012). The absence of published raw data is the most pressing limitation for multi-decadal studies along the transect.

Another potential source of data for analyses of the long-term monitoring surveys is natural history collections in museums. The aim of the present study is to test the applicability of extant museum collections from the Kola Meridian for long-term monitoring of benthic communities. We limited our study to shell-bearing Gastropoda because their species identification in many cases does not require examination of the soft body, which is often poorly preserved after a long storage. In addition, the shell provides better preservation of gastropods in museum collections compared to other groups of organisms.

\section{Materials and methods}

We studied collections stored at the Sciences ZIN and the $\mathrm{DH}$, both in Saint Petersburg, Russia. ZIN is the oldest and the largest zoological repository in Russia; it contains almost all extant historical samples from the Russian Arctic expeditions. However, the collections of K.M. Derjugin, including those from the Kola Meridian, are kept at the DH. We were unable to find information about the presence of significant historical collections from the Meridian kept by other Russian or foreign organizations.

The malacological collection of ZIN was regularly catalogued since the late 19th century. For this museum, we used the handwritten catalogue to find all extant samples collected along longitude $33^{\circ} 30^{\prime} \mathrm{E}\left( \pm 2^{\prime}\right)$ and northward to $69^{\circ} 30^{\prime}$ N. Samples from standard stations, that is, stations located at distances from the starting point divisible evenly by 30 minutes, and non-standard stations were examined. The DH collection is rather small and includes only dry gastropod shells, mainly used for educational purposes.

All molluscan specimens collected along the Kola Meridian were examined manually, and previous species identifications were verified based on comparing them with previously studied reference collections at European museums and in modern taxonomic literature-see Nekhaev \& Krol (2017) for a complete list of sources used for the taxonomic re-examination of materials.

For the comparison, we used two data sets from the previously published studies. The first ("early data") was compiled from the studies by Derjugin (1924) and Tanasijčuk (1927) and includes records of 47 species collected from stations 1-12 by trawls in 1921, 1922 and 1925. The second one ("recent data") is thoroughly described by Nekhaev \& Ljubin (2016). They used samples collected during 1995-2013 with grab samplers. This data set comprises records of 43 species from stations 1-10 (Supplementary Tables S1, S2).

\section{Results}

A total of 151 museum lots (a lot is all individuals of the same species from a particular station) collected along the Kola Meridian were found at the ZIN. Only six lots were obviously misidentified. However, taxonomical position of molluscs from 48 lots could not be identified with certainty. These specimens were either juveniles or in such poor condition that they could not be identified to the species level. Thirty-six of them belong to the genus Colus Roding, 1759 (family Buccinidae). The taxonomy of this genus is based on shell characters only. It has been 
recommended that accurate identification of Colus spp. requires an examination of the embryonic shell and siphonal channel, which are usually damaged on adult specimens (Bouchet \& Warén 1985). However, we used secondary minor characters such as shell shape and sculpture to recognize conchological forms that are believed to correspond to species identified by previous authors (e.g., Derjugin 1924; Tanasijčuk 1927).

Two lots from different stations contained empty adult shells of the littoral species Littorinalittorea (Linnaeus 1758), which has never been found alive far from the coast. These findings were discounted in our study because they are most likely artefacts.

Only eight lots from the Kola Meridian were found in the DH collection. All species identifications were verified by us.

In total, 37 species were identified in the museum lots (Fig. 1). Two species (Trichotropis borealis [Broderip et Sowerby 1829] and Calliostoma occidentale [Mighels et Adams 1842]) were found in the museum collections

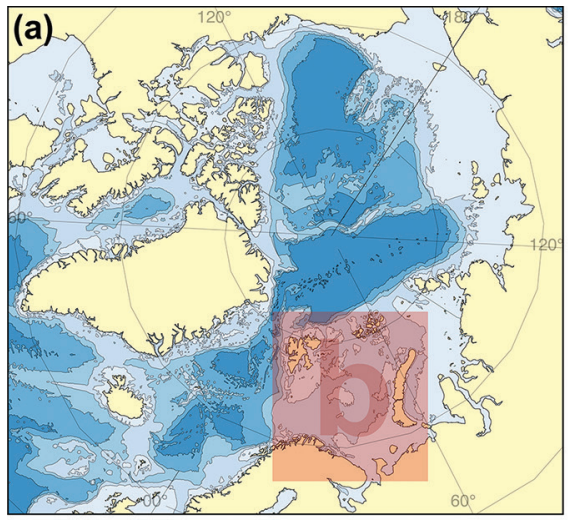

(c)

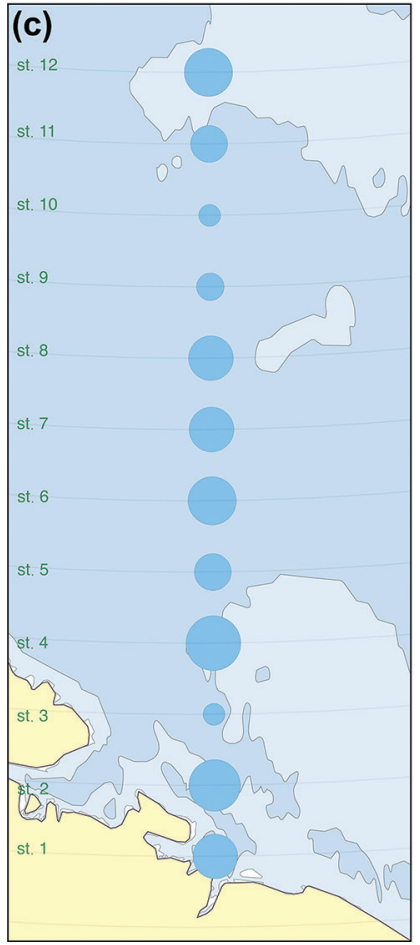

(d)
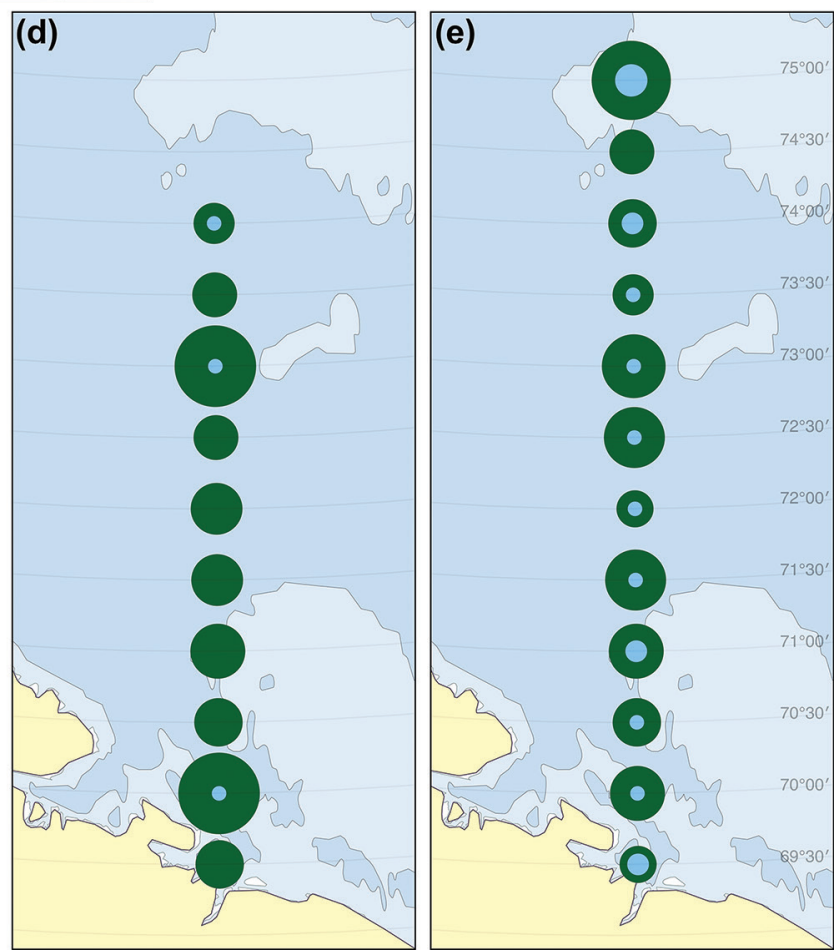

Fig. 1 (a, b) Position of the Kola Meridian and distribution of species diversity of shell-bearing gastropods along the transect according to (c) museum collections, (d) recent data and early data (for definitions of "early" and "recent" data, see the main text). Dot sizes are proportionate to the number of species found at a station; blue dots indicate the number of species shared with museum collections from the same station. 
exclusively between the standard stations of the transect and were known from the early and recent data. The museum collections contain 19 species shared with the early data and only 11 with the recent data; thus, the total number of species of shell-bearing gastropods known from the transect in all three data sets is 87. A total of 13 species found in museum collections were not noted in either the early or the recent data. The species composition of each station significantly differs between data obtained from museum collections and both early and recent data (Fig. 1).

The studied museum lots originated from 74 samples collected from stations $1-14,16$ and 18. This number also includes 12 samples collected between the standard stations of the Kola Meridian. The museum samples were collected from 1898 to 1991. The largest number of extant samples was collected in 1900 (22 samples), 1968 (12 samples) and 1901 (nine samples). More than half (40 samples) of the total number of extant samples was collected prior to 1920 .

\section{Discussion}

We found that the extant collections actually represent a small data array separate from both early and recent data. In addition to the fact that only a small portion of the collected material is available for reexamination, many specimens were unsuitable for further use since they did not contain parts of the shells important for their correct identification. It is important to note that the largest number of preserved lots belongs to the earliest period of research, when the bottom fauna was taken into account only in bycatch of commercial bottom trawls, whereas later specimens collected by grabs and dredgers are practically absent in the collections. Most likely, the differences between the data sets are associated with different methods of collecting material. The almost complete absence of collections of previous expeditions in the repositories does not allow the use of museum data as a baseline for monitoring. We believe that similar results would be obtained when studying other representatives of macrozoobenthos because the same approaches to collection, processing and storage of material are used for different groups of benthic organisms.

An equally important consequence of our study may be some distrust of published information as a source of baseline evidence for monitoring studies in the Barents Sea. An examination of museum collection is an essential stage for numerous taxonomic, faunistic and biogeographic studies. The published results of these investigations, for example, checklists, atlases and catalogues, also provide preliminary data used for suggestions about changes in the ecosystems. However, such sources can reflect the current state of museum collections rather than the real condition of ecosystems. The main source of information on the taxonomic composition of benthic invertebrate communities of the Barents Sea is the List of species of free-living invertebrates (Sirenko 2001), compiled on the basis of the ZIN collections. It includes benthic invertebrates collected along the Kola Meridian as a part of the Barents Sea fauna, but they are not marked as such. Researchers have worked under the assumption that Sirenko's species list includes all or the majority of faunistic data obtained during the previous surveys along the transect. Although so far there have been no attempts to verify the accuracy of this assumption, researchers have suggested that the majority of records of species not on the list represent range extensions resulting from recent climate changes. This interpretation has been proposed to account for the records of 37 crustacean species (Ljubina et al. 2012; Zimina \& Ljubina 2016), eight species of Gastropoda (Nekhaev 2014, 2017), seven Polychaeta species (Dikaeva et al. 2016), five Amphipoda species, three Bivalvia species (Frolov \& Manushin 2016) and other invertebrate species that were all recently recorded for the first time for the Barents Sea from the Kola Meridian. However, in light of our investigations, described herein, the discovery of species that are apparently new to the area may be attributed to incomplete data from earlier surveys rather than to actual climaterelated range changes.

In a broader context, numerous modern-day estimations of Arctic biodiversity and predictions of ecosystem changes due to climate change and other factors are based in full or partially on recent collection-based publications or databases (Loeng \& Drinkwater 2007; Wassmann et al. 2011 ). For example, popular scenarios of changes in the Arctic biota include the expected expansion of the ranges of many species of bottom invertebrates based on information on their distribution obtained from archival sources. No internationally standardized criteria are used to verify the reliability of this information (Wesławski et al. 2011; Renaud et al. 2015). We urge that more care be taken to verify the quality of the historical data when modern data are compared with museum collections or collection-based publications.

\section{Conclusion}

The storage of primary data is especially important in long-term studies, as it provides the ability to compare new data with previously obtained ones. By themselves, biological collections are primary material, and their preservation ensures the verifiability of scientific research 
(Salvador \& Cuncha 2020). Museum samples are available for re-study by taxonomists and therefore have a higher priority as a source of primary information compared to text archives. We also suggest that the storage of zoological materials in public collections should be an essential part of long-term monitoring programmes. Ideally, protocols of storage and usage of primary material should be assessed at all stages of such projects, from the application for funding to the publication of the results.

\section{Acknowledgements}

We express our gratitude to Rodrigo Salvador (Wellington, New Zealand) and two anonymous reviewers for their useful comments to the first version of the manuscript.

\section{Funding}

The work by IN (conceptualization, re-examination of collections at the ZIN and DH, data analysis and preparation of the manuscript) was supported by the Russian Science Foundation (project no. 18-74-00010). The work by AM (examination of the ZIN catalogue and collections, and comments on the first version of the manuscript) was a part of Basic State Assignment AAAA-A19-119020690072-9.

\section{Disclosure statement}

The authors report no conflict of interest.

\section{References}

Anonymous 1900. International conference for the exploration of the sea, Stockholm, 1899. Journal of the Marine Biological Association of the UK 6, 101-114, doi: 10.1017/ S0025315400072416.

Anonymous 1902. The second international conference for the exploration of the sea, Christiania, 1901. Journal of the Marine Biological Association of the UK 6, 389-391, doi: $10.1017 /$ S0025315400043630.

Boitsov V.D., Karsakov A.L. \& Trofimov A.G. 2012. Atlantic water temperature and climate in the Barents Sea, 2000-2009. ICES Journal of Marine Science 69, 833-840, doi: 10.1093/icesjms/fss075.

Bouchet P. \& Warén A. 1985. Revision of the Northeast Atlantic bathyal and abyssal Neogastropoda excluding Turridae (Mollusca, Gastropoda). Bolletino Malacologico, Supplemento 1, 123-296, doi: 10.5962/bhl.title.140763.

Derjugin K.M. 1924. Barencevo more po Kol'skomu meridianu $\left(33^{\circ} 30^{\prime}\right)$. Trudy Severnoy Naučno-promyslovoy Ekspedicii. Vypusk 19. (The Barents Sea along the Kola Transect [3330'].
Proceedings of northern scientific and commercial expedition. Issue 19.) Moscow/Leningrad: Naučno-tehničeskij otdel Vysšego Soveta Narodnogo Hozjajstva.

Dikaeva D.R. 2009. Modern distribution of polychaetes along the Kola Section (Barents Sea). Doklady Biological Sciences 426, 282-284, doi: 10.1134/S0012496609030260.

Dikaeva D.R., Frolova E.A. \& Vjaznikova V.S. 2016. Vidovoj sostav, količestvennoe raspredelenie i dinamika soobščestv polihet na razreze "Kol'skij Meridian". (Specific composition, quantitative distribution and dynamics of Polychaeta communities on the transect "Kola Section".) Trudy Kol'skogo Naučnogo Centra 36, 143-166.

Frolov A.A. \& Manušin I.E. 2016. Prostranstvennovremennaja structura poselenij dvustvorčatyh molljuskov na razreze "Kol'skij Meridian". (Spatial and temporal structure of bivalve settlements along the transect "Kola Section".) Trudy Kol'skogo Naučnogo Centra 36, 166-169.

Frolova E.A., Ljubina O.S., Dikaeva D.R., Akhmetčina O.Y. $\&$ Frolov A.A. 2007. Effect of climatic changes on the zoobenthos of the Barents Sea (on the example of several abundant species). Doklady Biological Sciences 416, 349-351, doi: 10.1134/S0012496607050079.

Loeng H. \& Drinkwater K. 2007. An overview of the ecosystems of the Barents and Norwegian seas and their response to climate variability. Deep-Sea Research Part II 54, 2478-2500, doi: 10.1016/j.dsr2.2007.08.013.

Ljubina O.S., Zimina O.L. \& Anisimova N.A. 2012. Distribution and variation of the amphipod fauna (Crustacea, Amphipoda) in the Kola Section (Barents Sea). Doklady Biological Sciences 442, 27-30, doi: 10.1134/ S0012496612010061.

Nekhaev I.O. 2014. Marine shell-bearing Gastropoda of Murman (Barents Sea): an annotated check-list. Ruthenica: Russian Malacological Journal 24, 75-121.

Nekhaev I.O. 2017. New records of molluscs of the families Eulimidae and Pyramidellidae (Gastropoda) from the Barents Sea and adjacent Polar Basin. Ruthenica: Russian Malacological Journal 27, 59-63.

Nekhaev I.O. \& Krol E.N. 2017. Diversity of shell-bearing gastropods along the western coast of the Arctic archipelago Novaya Zemlya: an evaluation of modern and historical data. Polar Biology 40, 2279-2289, doi: 10.1007/ s00300-017-2140-1.

Nekhaev I.O. \& Ljubin P.A. 2016. Brjuhonogie i lopatonogie molluski na gidrobiologičeskom razreze "Kol'skij Meridian". (Gastropods and scahopods of the "Kola Section" hydrobiological transect.) Trudy Kol'skogo Naučnogo Centra 36, 232-245.

Nessis K.N. 1960. Izmenenija donnoj fauny Barenceva morja pod vlijaniem kolebanij gidrologičeskogo režima (na razreze Kol'skij Meridian). (Changes in bottom fauna of the Barents Sea under the influence of hydrological regime [along the Kola Meridian Transect].) In Sovetskie rybohozjajstvennye issledovanija $v$ morjah evropejskogo severa. (Soviet fishery investigations in the seas of the European North.) Pp. 129-137. Moscow: All-Russia Research Institute of Marine Fisheries and Oceanography. 
Renaud P.E., Sejr M.K., Bluhm B.A., Sirenko B. \& Ellingsen I.H. 2015. The future of Arctic benthos: expansion, invasion, and biodiversity. Progress in Oceanography 139, 244-257, doi: 10.1016/j.pocean.2015.07.007.

Sirenko B.I. (ed.) 2001. List of species of free-living invertebrates of Eurasian Arctic seas and adjacent deep waters. St. Petersburg: Zoological Institute of Russian Academy of Sciences.

Strelkova N.A. 2016. Istorija izučenija bentosa na razreze "Kol'skij Meridian". (History of benthic research on the transect "Kola Section".) Trudy Kol'skogo Naučnogo Centra $36,7-29$.

Salvador R.B. \& Cunha C.M. 2020. Natural history collections and the future legacy of ecological research. Oecologia 192, 641-646, doi: 10.1007/s00442-020-04620-0.

Tanasijčuk N. 1927. Zoologische ergebnisse der terminfahrt bis zum $75^{\circ} \mathrm{n}$. br. längs des Kola-Meridians (BarentsMeer) im August 1925. (Zoological results of the expedition up to $75^{\circ} \mathrm{N}$ along the Kola meridian [Barents Sea] in August 1925.) Comptes Rendus de l'Académie des Sciences de l'URSS 6, 359-363.

Tande K.S., Drobysheva S., Nesterova V., Nilssen E.M., Edvardsen A. \& Tereschenko V. 2000. Patterns in the variations of copepod spring and summer abundance in the northeastern Norwegian Sea and the Barents Sea in cold and warm years during the 1980s and 1990s. ICES Journal of Marine Science 57, 1581-1591, doi: 10.1006/ jmsc.2000.0982.

Titov O.V. 2001 . Long-term variations in the hydrochemical and density characteristics over the Kola meridian section as an indicator of changes in the ecosystem of the Barents Sea. Oceanology 41, 493-501.

Wassmann P., Duarte C.M., Agustí S. \& Sejr M.K. 2011. Footprints of climate change in the Arctic marine ecosystem. Global Change Biology 17, 1235-1249, doi: 10.1111/j.1365-2486.2010.02311.x.

Wesławski J.M., Kendall M.A., Włodarska-Kowalczuk M., Iken K., Kedra M., Legezynska J. \& Sejr M.K. 2011. Climate change effects on Arctic fjord and coastal macrobenthic diversity-observations and predictions. Marine Biodiversity 41, 71-85, doi: 10.1007/ s12526-010-0073-9.

Zimina O.L. \& Ljubina O.S. 2016. Donnye rakoobraznye nadotrjada Pericarida na razreze "Kol'skij Meridian". (Peracarida [Crustacea, Malacostraca] of the Kola Section.) Trudy Kol’skogo Naučnogo Centra 36, 196-221. 